\title{
The Annual Meeting of the Lithuanian Association of the History and Philosophy of Science
}

The COVID-19 pandemic has affected everyone's lives, including those of scholarly societies and organizations. All of us have had to adjust to new forms of communication and human interaction. Some of this has been for the good. Virtual meetings allow for greater participation by a greater number of people from different parts of the country or the world. There are no travel, rental or food costs. In the short term this is good, but in the long term we still need a personal contact with our colleagues: to better know them as people as well as scholars, to meet new people and form networks and partnerships, to visit interesting places and venues.

Every year, in spring, the Lithuanian Association of the History and Philosophy of Science (LAHPS) holds its annual meeting Scientia et historia. The first wave of the pandemic hit us hard already last spring when Lithuania declared a quarantine and lockdown in March. We were not able to hold our annual meeting that was dedicated to the centennial of the School of Higher Studies, which was established in Kaunas in 1920 and became the foundation for the University of Lithuania (1922). Later, in 1930, this university changed its name to Vytautas Magnus University. We asked speakers on that topic to prepare scholarly articles which we then posted on the LAHPS website.

This year, on March 25-26, we were able to organize a virtual conference via Zoom. It was dedicated to four well-known scientists and scholars in the history and philosophy of Lithuanian science: the Franciscan priest, botanist and educator Jurgis Ambrozijus Pabrèža (1771-1849); the astronomer, mathematician and one of the founders of the LAHPS Paulius Slavenas (1901-1991); the archeologist and anthropologist Marija Gimbutas (1921-1994); and the physicist, historian of science and philosophy, long-term president of the LAHPS and active member of the Baltic Association of the History and Philosophy of Science (BAHPS) Juozapas A. Krikštopaitis (1931-2018).

The two-day conference consisted of four sessions and 25 presentations (all in Lithuanian). There was also a General Assembly and the business meeting of the Association. The first session (moderated by Ramūnas Kondratas) featured three presentations on the life and work of Jurgis A. Pabrěža and four on Marija 
Gimbutas. The second session was moderated by the philosopher of science Alvydas Noreika and included a presentation by Libertas Klimka, a long-term member of LAHPS and BAHPS, on the contributions of Paulius Slavenas to the history of science. The third session, which was moderated by Romualdas Juzefovičius, featured presentations on the history of medicine and pharmacy. Ramūnas Kondratas spoke about the medical and social contributions of the Lithuanian-American cardiologist and inventor Bernard Lown (1921-2021), who in 1985 accepted the Nobel Peace Prize on behalf of the International Physicians for the Prevention of Nuclear War, an organization he co-founded with the Soviet cardiologist Yevgeny Chazov. Lown died in February this year, a few months short of his 100th birthday. Edmundas Kutkus spoke about Lown's Jewish roots and Jewish life in Lown's native town of Utena. Viktorija Šimkute and Monika Ramonaite presented an interesting talk on their experience in establishing a Facebook discussion group on the history of medicine and pharmacy. This was done in March of 2020 as a response to the pandemic quarantine. It already has 300 participants and 800 followers. The fourth session was moderated by Vilma Gudienè and featured a presentation by Biruté Railiené, the academic secretary of the LAHPS, about her new book co-authered with Neringa Markauskaite on the Portraits of Jędrzej Śniadecki (Vilnius: Lietuvos mokslų akademijos biblioteka, 2020).

For the first time, the LAHPS has published its conference abstracts. They can be found on the Association's website (http://www.moksloistorija.lt/konferencijosscientia-et-historia-2021-pranesimu-tezes/). The booklet was edited by the association's president Ramūnas Kondratas and contains welcoming remarks by the president, a six-page article by Birute Railiene on the history of the LAHPS, the conference program and 25 abstracts. The conference organizers are pleased with the number of participants (35-40) and the very lively discussions (some extending into the breaks). Our mission is to reach out and attract as many people throughout Lithuania as we can who are interested in the history of science, medicine and technology as well as philosophy of science. This conference was an important first step.

\section{Dr. Ramunas Kondratas}

Lithuanian Association of the History and Philosophy of Science 